Palestine Exploration Quarterly

\title{
Meteorological Observations Taken in the City of Jerusalem, 1912
}

\section{Adolph Datzi}

To cite this article: Adolph Datzi (1913) Meteorological Observations Taken in the City of Jerusalem, 1912, Palestine Exploration Quarterly, 45:2, 102-102, DOI: 10.1179/ peq.1913.45.2.102

To link to this article: http://dx.doi.org/10.1179/peq.1913.45.2.102

Published online: 19 Jul 2013.

Submit your article to this journal $\sqsubset$

Џ Article views: 2

Q View related articles $\square$ 
METEOROLOGICAL OBSERVATIONS.

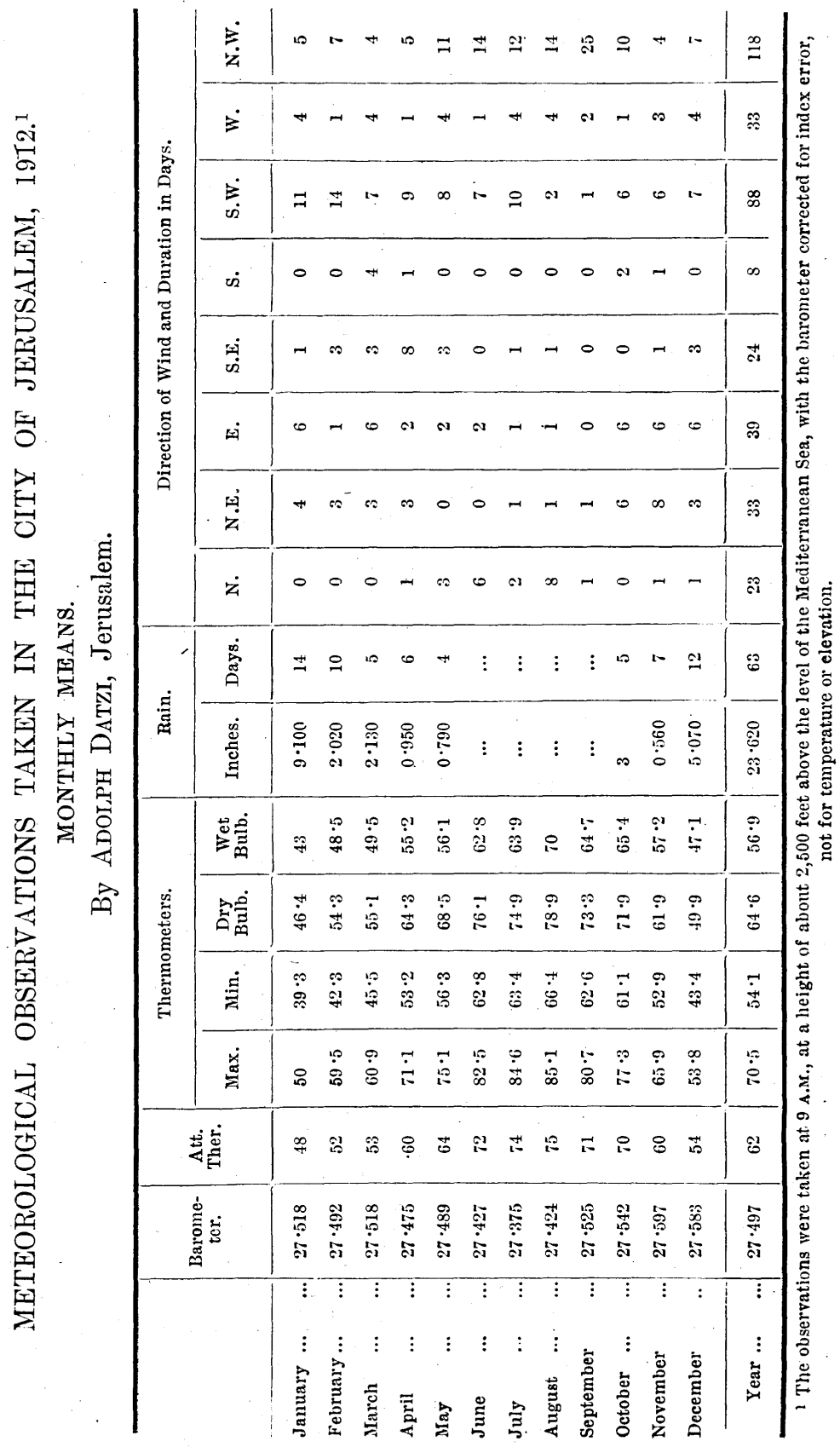

